\title{
EFFECT OF FOLIAR APPLICATION OF MICROELEMENTS AND POTASSIUM LEVELS ON GROWTH, PHYSIOLOGICAL AND QUALITY CHARACTERS OF SUGAR BEET (Beta vulgaris L.) UNDER NEWLY RECLAIMED SOILS \\ Abdelaal, Kh.A.A. ${ }^{1}$; Shimaa, A. Badawy ${ }^{2}$ and Shahrzd, M.M.Neana ${ }^{3}$ ${ }_{1}^{1}$ Agricultural botany Dept., Fac. Agric., Kafrelshiekh University, Egypt. ${ }^{2}$ Agronomy Dept., Fac. Agric., Kafrelshiekh University, Egypt. ${ }^{3}$ Sugar Crops Research Institute, Agricultural Research Center.
}

\section{ABSTRACT}

Two field experiments were conducted during two successive seasons 2012/2013 and 2013/2014 at Nubaria area, Alexandria Governorate, in order to study the effect of foliar application of $\mathrm{B}, \mathrm{Fe}, \mathrm{Zn}$ and $\mathrm{Mn}$ at the concentrations of 1.0, 1.5 and $2.0 \mathrm{~L} / 400 \mathrm{~L}$ water/fed and potassium fertilizer levels (24, 36 and $48 \mathrm{~kg} \mathrm{~K} \mathrm{~K}_{2} \mathrm{O} / \mathrm{fed}$.) on yield and physiological characters of sugar beet plant (Beta vulgaris L.) under newly reclaimed soils.

A split plot design with four replications was used. Results revealed that foliar application of $\mathrm{B}, \mathrm{Fe}, \mathrm{Zn}$ and $\mathrm{Mn}$ at the concentration of $1.5 \mathrm{l} / \mathrm{fed}$ recorded highest root diameter and root fresh weight/plant, as well as, sucrose\%, root and sugar yields/fed., while, foliar application of $\mathrm{B}, \mathrm{Fe}, \mathrm{Zn}$ and $\mathrm{Mn}$ at the concentration of at $2 \mathrm{l} / \mathrm{fed}$ gave tallest root and percentage of root impurities ( $\alpha$ - amino-N, Na and K). Fertilization of potassium at rate of $48 \mathrm{~kg} \mathrm{~K} 2 \mathrm{O} / \mathrm{fed}$ gave highest values of root length, root diameter, the percentage of $\alpha-\mathrm{N}, \mathrm{Na}, \mathrm{K}$ as well as root and sugar yields/fed in both seasons. On the contrary, a gradual reduction in sucrose $\%$ had been detected with the increase in potassium level over $36 \mathrm{~kg} \mathrm{~K} 2 \mathrm{O} / \mathrm{fed}$, while application of potassium at rate of $24 \mathrm{~kg}$ $\mathrm{K}_{2} \mathrm{O} / \mathrm{fed}$ recorded the lowest values in all characters in both seasons. The interaction between foliar spraying of $\mathrm{B}, \mathrm{Fe}, \mathrm{Zn}$ and $\mathrm{Mn}$ at the concentration of $1.5 \mathrm{l} / \mathrm{fed}$ and potassium fertilizer at rate of $48 \mathrm{~kg} \mathrm{~K} \mathrm{O}$ /fed significantly affected root and sugar yields/fed and sucrose\% in both seasons.

It could be summarized that, application of potassium at rate of $48 \mathrm{~kg} \mathrm{~K} \mathrm{~K}_{2} \mathrm{O}$ /fed and foliar spraying of $\mathrm{B}, \mathrm{Fe}, \mathrm{Zn}$ and $\mathrm{Mn}$ at the concentration of $1.5 \mathrm{l} / \mathrm{fed}$ significantly $\mathrm{k}$, affected root diameter and root fresh weight, root and sugar yields/fed. as well as sucrose\%

\section{INTRODUCION}

Sugar beet (Beta vulgaris L.) one of the most important genus of Chenopodiaceae family, its family includes approximately 1400 species (Watson and Dallwitz, 1992). Sugar beet became one of the important sugar crops; its roots are processed into white sugar, pulp and molasses for food, feed or industrial applications and are rarely used as a raw commodity. A typical sugar beet root consists of $75.9 \%$ water, $2.6 \%$ non-sugars, $18.0 \%$ sugar and $5.5 \%$ pulp. In the sugar fraction $83.1 \%$ is recovered as crystalline sucrose, $12.5 \%$ is recovered as molasses (Bichsel, 1987). Sugar beet plays a prominent role for sugar production, about $37.27 \%$ of locally sugar production, (CCSC, 2010), it grows well in the new reclaimed soils; maturity take short time compared to sugar cane and contains high sugar content. Many environmental and agronomic factors influenced sugar beet quantity and quality as fertilization and sowing methods. Improvement of sugar beet 
production can be achieved through application of potassium and sulphur fertilizer.

Sugar beet nutrition had a great effect on beet productivity. For various crops, micronutrients fertilizers received great attention. Osman (1997) and Abd El-Gawad et al., (2004) found that Mn application at a level of $40 \mathrm{~g} / \mathrm{fed}$ significantly raised purity\%. Gezgin et al., (2000) found that foliar application of $B$ levels from 0,500 and/or $750 \mathrm{~g} /$ boron as (sodium borate $11 \%$ B) increased significantly root and sugar yields via the increase in root sucrose \%. Osman et al., (2004) reported that foliar application of three levels of boron 0,1 and $2 \mathrm{Kg} / \mathrm{fed}$ (as a borax, sodium borate $11 \% \mathrm{~B}$ ) and 2 levels of $\mathrm{Mn}(0$ and $1 \mathrm{Kg} / \mathrm{fed}$.) as a manganese sulfate $(28 \% \mathrm{Mn})$ and the mixture of them $2 \mathrm{~kg} . \mathrm{B}+1 \mathrm{~kg} \mathrm{Mn} / \mathrm{fed}$. The results revealed that, surpassed in root length, TSS\%, sucrose\%, root and sugar yields/fed. Shafika and El-Masry (2006) found that foliar spray with micronutrients, in mixtures of $\mathrm{Zn}, \mathrm{Mn}$ and $\mathrm{Fe}$ increased significantly root growth, quality traits\%, root and sugar yields/fed. El-Geddawy et al., (2007 and 2008) showed that soaking sugar beet seeds with soulutions of micronutrients 0.5 and/or $1 \mathrm{~kg} \mathrm{~B} / \mathrm{fed}+4 \mathrm{~kg}$ $\mathrm{Zn} / \mathrm{fed}$ before sowing significantly surpassed the dried method with respect to root diameter, weight/plant, root and sugar yield/fed. Soudi and El-Guibali (2008) and Manal, Hussein (2011) found that foliar application with $(B+Z n+$ $\mathrm{Mn}+\mathrm{Fe}$ ) at the level $2 \mathrm{~cm} / / / 400$ I water/fed increased significantly root length, diameter, fresh weight/plant, as well as, sucrose\%, root and sugar yields/fed. in studied seasons as compared with control treatment (without micronutrients) and $1 \mathrm{~cm} / / / 400$ I water/fed. Hellal et al., (2009) concluded that in calcareous soil, high level of calcium carbonate are present. Boron should be applied to improve the yield and nutrient balance of sugar beet. ElMaghraby et al., (1998) and Khalil et al., (2001) found that sucrose, total soluble solids and purity of sugar beet juice increased with increasing $\mathrm{K}$ level. Further, it was found that quality and quantity of sugar in sugar beet roots, was enhanced by K fertilization (El-Harriri and Gobarh, 2001).

Potassium play an important role in regulating osmotic potential, increasing water uptake ability of sugar beet plants (Zengin et al., 2009). Potassium is essential for growth and is the main element used to regulate the water content of the plant (Rengel and Damon, 2008). EL-Shafai (2000) showed that increasing potassium application from zero up to $48 \mathrm{~kg} \mathrm{~K}_{2} \mathrm{O} / \mathrm{fed}$ significantly increased root yield. Ismail et al., (2002) found that potassium fertilizer significantly affected root fresh weight and root and sugar yields in two seasons, while sucrose $\%$ was significantly responded in the $1^{\text {st }}$ season only. Highest top yield was recorded with application of $24 \mathrm{~kg} \mathrm{~K}_{2} \mathrm{O} / \mathrm{fed}$. Alaa et al., (2009) reported that root yield, sucrose\%, white sugar\% and sugar yield were significantly increased by adding 24 or $48 \mathrm{~kg} \mathrm{~K}_{2} \mathrm{O} / \mathrm{fed}$ compared with control, they added that potassium rate had no significant effect on Kcontent and $\alpha$-amino nitrogen content. Nafei et al (2010) reported that kfertilizer level at $36 \mathrm{~kg} \mathrm{~K} \mathrm{~K}_{2} \mathrm{O} / \mathrm{fed}$ increased root length, root diameter, fresh weight /plant and root yield in both season as well as sugar yield in the $1^{\text {st }}$ season. Root and sugar yields of sugar beet significantly increased with potassium application at the rate of $114 \mathrm{~kg} / \mathrm{ha}$ (Abdel-motagally et al., 2009). Mahdi and Mohammad (2012) reported that potassium application increased 
root yield, shoot yield, impure sugar percent, pure sugar percent and sugar yield. Salami and Saadat (2013) and Nabila et al., (2014) found that potassium significantly increased all the studied yield characters except shoot / root ratio and root diameter. In recent years, sugar beet grown on sandy soils as newly reclaimed soils has shown a variety of visual symptoms that resemble nutrients deficiencies.

Furthermore, the objectives of this investigation aimed to study the effect of foliar application of $\mathrm{B}, \mathrm{Fe}, \mathrm{Zn}$ and $\mathrm{Mn}$ at different concentrations and potassium fertilizer rates as well as their interaction on growth, physiological characters and quality of sugar beet, cv. Lola under newly reclaimed soils.

\section{MATERIALS AND METHODS}

Two field trials were conducted at Nubaria, Alexandria Governorate during $2012 / 2013$ and $2013 / 2014$ seasons to study the effect of three foliar spray of $\mathrm{B}, \mathrm{Fe}, \mathrm{Zn}$ and $\mathrm{Mn}$ at 1.0, 1. 5 and $2.0 \mathrm{~L} / 400 \mathrm{~L}$ water/fed at 45 and 75 days from sowing date and three potassium fertilizer rates at 24,36 and 48 $\mathrm{kg} \mathrm{K} \mathrm{K}_{2} \mathrm{O} / \mathrm{fed}$ on growth, physiological characters and quality of sugar beet (Beta vulgaris L.). The foliar application of some micronutrients solution comprise of liquid chelated microelements, $\mathrm{B}, \mathrm{Fe}, \mathrm{Zn}$ and $\mathrm{Mn}$, i.e. boron in the form of boric acid $9 \% \mathrm{~B}$, iron in the form of iron chelated (7.15\% iron oxide), zinc in the form of zinc chelated ( $7 \%$ zinc) and Manganese in the form of manganese chelated $(9.03 \%$ manganese oxide), which were sprayed at 45 and 75 days after sowing by using manual sprayer with $400 \mathrm{l} / \mathrm{fed}$. The treatments were distributed in a split plot design with four replications, the foliar spray with microelements rates were allocated in the main plots, whereas, fertilizer with potassium rates distributed in the sub plots. The sub plot area was $19.60 \mathrm{~m}^{2}$ including four ridges of $7 \mathrm{~m}$ in length and $70 \mathrm{~cm}$ apart and spacing between hills was $20 \mathrm{~cm}$.

Seeds of sugar beet Lola variety were sown at $10^{\text {th }}$ and $20^{\text {th }}$ October and harvested after 7 months for the $1^{\text {st }}$ and $2^{\text {nd }}$ seasons, respectively. Nitrogen fertilizer at rate of $120 \mathrm{~kg} \mathrm{~N} / \mathrm{fed}$ in the form of ammonium nitrate $(33.5 \% \mathrm{~N})$ was applied in four equal doses, the first was applied after thinning and the others were applied at 2-weeks interval after the first application. Phosphorus fertilizer at a rate of $30 \mathrm{~kg} / \mathrm{fed}$ in the form of calcium super phosphate $\left(15.5 \% \quad \mathrm{P}_{2} \mathrm{O}_{5}\right)$ was added during land preparation. Potassium fertilizer at a rate of 24,36 and $48 \mathrm{~K}_{2} \mathrm{O} / \mathrm{fed}$ in the form of potassium sulfate $\left(48.5 \% \mathrm{~K}_{2} \mathrm{O}\right)$ was applied in four equal doses with nitrogen fertilizer. The preceding crop was Maize at both seasons. Other agricultural practices for sugar beet field were carried out as recommended by Sugar Crops Research Institute.

Some physical and chemical analysis of the experimental site are conducted according to A.O.A.C. (2005) and the data shown in Table 1. 
Table 1. Physical and chemical analysis of the experimental site.

\begin{tabular}{|c|c|c|c|c|c|c|c|c|c|c|c|c|}
\hline \multirow[b]{2}{*}{ Seasons } & \multicolumn{3}{|c|}{ Partial size \% } & \multirow{2}{*}{\begin{tabular}{|c|} 
Soil \\
Textural \\
$\%$
\end{tabular}} & \multirow{2}{*}{$\begin{array}{l}\text { Soil } \\
\mathrm{pH} \\
1: 2.5\end{array}$} & \multirow{2}{*}{$\begin{array}{l}\text { E.C*. } \\
\text { ds/m }\end{array}$} & \multirow{2}{*}{$\underset{\%}{\mathrm{CaCO}_{3}}$} & \multirow{2}{*}{$\begin{array}{l}\text { Organic } \\
\text { matter\% }\end{array}$} & \multicolumn{4}{|c|}{$\begin{array}{c}\text { Available contents } \\
\%\end{array}$} \\
\hline & Clay & Silt & Sand & & & & & & \begin{tabular}{|l|}
$\mathbf{N}$ \\
\end{tabular} & $\mathbf{P}$ & & $\mathbf{K}$ \\
\hline & 3.0 & 3.3 & \begin{tabular}{|l|}
93.7 \\
\end{tabular} & Sandy & \begin{tabular}{|l|}
7.7 \\
\end{tabular} & 1.6 & $10.6 \%$ & 0.75 & 4.4 & 3.2 & & 132 \\
\hline & 3.6 & 4.7 & 91.7 & Sandy & 7.8 & 1.9 & $9.9 \%$ & 0.90 & 6.5 & 3.0 & & 120 \\
\hline \multirow{2}{*}{ Seasons } & \multicolumn{4}{|c|}{ Soluble cations (meq/l) } & \multicolumn{4}{|c|}{ Soluble anions (meq/l) } & \multicolumn{4}{|c|}{$\begin{array}{c}\text { Available contents } \\
(\mathrm{ppm})\end{array}$} \\
\hline & $\mathrm{Ca}++$ & $\begin{array}{c}\mathrm{Mg}+ \\
+\end{array}$ & $\mathrm{Na}+$ & $\mathrm{K}+$ & $\mathrm{CO}$ & $\pi C O 3-$ & Cl- & SO4- & B & $\mathrm{Fe}$ & $\mathrm{Zn}$ & $\mathrm{Mn}$ \\
\hline & 2.00 & 3.02 & 3.24 & & 2.50 & & 3.0 & & 0.3 & 4.2 & 2 & 3.8 \\
\hline $2013 / 2014$ & 2.05 & 3.00 & 3.14 & 0.35 & 2.60 & 1.09 & 3.00 & 2.10 & 0.35 & 4.1 & 3.5 & 2.4 \\
\hline
\end{tabular}

*In the soil paste extract.

At harvest time (210 days from sowing): A sample of 10 roots was randomly taken to determine the following characters:

\section{Root growth traits:}

*Root length (cm/plant). $\quad$ *Root diameter (cm/plant).

${ }^{*}$ Root fresh weight (g/plant). $\quad{ }^{*}$ Root yields (ton/fed.) were determined on the whole plot basis were harvested, topped and weighed to determine root yields/fed.

\section{Physiological and quality characteristics:-}

*Sucrose\%: was polar-metrically determined on a lead acetate extract of fresh macerated root according to Le Docte (1927).

${ }^{*}$ Root impurities $\{\alpha$-amino nitrogen, sodium and potassium contents (meq $/ 100 \mathrm{~g}$ beet)\} were estimated according to the procedure described by the Sugar Company using Auto Analyzer.

The analysis of variance was carried out according to Gomez and Gomez (1984) for all collected data. Treatment means were compared by Duncan's Multiple Range test according to Duncan (1955). All statistical analysis was performed using analysis of variance technique by means of "MSTATC" computer software package.

\section{RESULTS AND DISCUSSION}

Effect of foliar application of microelements concentrations on growth yield, physiological characters and quality of sugar beet.

Results presented in Tables 2, 3 and 4 indicated that foliar spray with $\mathrm{B}, \mathrm{Fe}, \mathrm{Zn}$ and $\mathrm{Mn}$ at the rate of $1.5 \mathrm{l} / \mathrm{fed}$ gave highest for root diameter and root fresh weight than foliar spraying at a rate of 1.0 or $2.0 \mathrm{l} / \mathrm{fed}$. The same results were obtained for juice quality as sucrose $\%$ and purity $\%$ as well as root and sugar yields in both seasons. On the other hand, foliar application of $\mathrm{B}, \mathrm{Fe}, \mathrm{Zn}$ and $\mathrm{Mn}$ at rate of $2.0 \mathrm{l} / \mathrm{fed}$ gave highest root length and root impurities, i.e., $\alpha-\mathrm{N}, \mathrm{Na}$ and $\mathrm{K} \%$ than other micronutrients levels. This intensive competition was compensated by a sufficient increase in root fresh weight/plant, sucrose $\%$ as well as root and sugar yield. The stimulation effects of micronutrients on quality traits may be attributed to the increase in sucrose\%. Boron is essential for the formation of new cells in meristems in addition to a vital role in sugar translation to roots. Manganese activates some of the enzyme reactions; it plays a role in regulating the levels of Auxin 
in plant tissues by activating the Auxin Oxidase system (Marschner, 1986). Furthermore, $\mathrm{Mn}$ acts as an activator for different enzymes, especially those of the interactions of Kerbs cycle and protein synthesis within the plant. The role of $\mathrm{Fe}$ as an electron carrier in photosynthetic phosphorylation and $\mathrm{N}$ fixation, in addition to its role in building-up chlorophyll and the activity of metal of lavoprotein, which may be reflected on plant performance. The role of $\mathrm{Zn}$ in enhancement the vegetative growth, might be due to that $\mathrm{Zn}$ is known to be an essential constituent of three plants enzyme i.e. carboning anhydrase, alchohol dehydrogenase and superoxidase dismutase. In addition, $\mathrm{Zn}$ has a marked effect on the level of Auxin which appears to be required in the synthesis of intermediates in the metabolic pathway, through tryptophan to Auxin (Ohki, 1978) which in turn encourage the meristemic activity of the plant which resulted in more cell enlargement (Devlin and Witham, 1983). Sandman and Bogger (1983) stated that yield increment might be due to the favorable influence of $\mathrm{Zn}$ on plant enzyme activity and improving the photosynthetic and mobilization in plants. The pronounced effect of micronutrients is mainly due to their effect on growth hormones production which has a direct effect on plant growth, throughout their influence on the production of plant growth promoting substances and increase in various availability soil nutrients. These results are in agreement with those reported by El-Geddawy et al., (2007 and 2008); Soudi and ElGuibali (2008); Manal, Hussein (2011) and Awad et al. (2013 a).

\section{Potassium fertilizer effects:}

Results in Tables 2, 3 and 4 showed that potassium fertilizer levels led to significant differences in root length, diameter, fresh weight, sucrose $\%$ as well as, root and sugar yields/fed and $\alpha-\mathrm{N}, \mathrm{Na}$ and $\mathrm{K} \%$ in both seasons. Fertilization of potassium at rate of $48 \mathrm{~kg} \mathrm{~K} \mathrm{~K}_{2} \mathrm{O} / \mathrm{fed}$ gave the highest mean values for root length, diameter and fresh weight $\mathrm{g} / \mathrm{plant}$ as well as root and sugar yields/fed, while, it gave the lowest percentages of sucrose. Similar results were obtained by Osman (2005) who found that froths criteria of sugar beet plants were significantly increased with increasing level of potassium fertilization up to $48 \mathrm{~kg} \mathrm{~K}_{2} \mathrm{O} / \mathrm{fed}$. These results are in agreement with Abdelmotagally et al., (2009), Salami and Saadat (2013) and Nabila et al. (2014).These results are in harmony with those obtained by Ulgen et al. (2009) found that potassium positively affects sugar content because of its specific physiological effects during synthesis, transport and storage of sugars. Potassium enhances many enzyme actions aids in photosynthesis process and sugar formation and translocation. The role of potassium in making active enzymes cells division and growing, opening and closing of stomata and loading carbohydrates on phloem are the main cases of increase of root yield, by increasing on consume values of potassium (Taiz and Zeiger 2006). Furthermore, Karam et al., (2009) reported that Potassium also has another equally important role in the transfer of sugars produced in the leaves to the storage root. In its passage from leaf to storage root each molecule of sugar has to pass through in numerable cell membranes, and $\mathrm{K}^{+}$ ions are an essential component of the 'molecular pump' within the cell membranes that facilitate this passage. 
Table 2: Effect of foliar spraying of mixture of microelements rates and potassium levels on some roots growth traits during 2012/2013 and 2013/2014 seasons.

\begin{tabular}{|c|c|c|c|c|c|c|}
\hline Traits & \multicolumn{3}{|c|}{ 2012/2013 season } & \multicolumn{3}{|c|}{ 2013/2014 } \\
\hline $\begin{array}{c}\text { Micoelements } \\
\text { rates }\end{array}$ & \multicolumn{3}{|c|}{ Root growth traits } & \multicolumn{3}{|c|}{ Root growth traits } \\
\hline$(1 /$ fed. $)$ & $\begin{array}{c}\text { Root } \\
\text { length }\end{array}$ & $\begin{array}{c}\text { Root } \\
\text { diameter }\end{array}$ & $\begin{array}{c}\text { Root } \\
\text { Fresh weight }\end{array}$ & $\begin{array}{c}\text { Root } \\
\text { length }\end{array}$ & $\begin{array}{c}\text { Root } \\
\text { diameter }\end{array}$ & $\begin{array}{c}\text { Root } \\
\text { Fresh weight }\end{array}$ \\
\hline 1.0 & $27.47 \mathrm{c}$ & $11.33 \mathrm{~b}$ & $926.36 \mathrm{c}$ & $27.84 \mathrm{c}$ & $10.80 \mathrm{~b}$ & $968.6 \mathrm{c}$ \\
\hline 1.5 & $29.47 \mathrm{~b}$ & $11.74 \mathrm{a}$ & $973.37 \mathrm{a}$ & $30.95 \mathrm{~b}$ & $11.42 \mathrm{a}$ & $1004.3 \mathrm{~b}$ \\
\hline 2.0 & $31.82 \mathrm{a}$ & $11.88 \mathrm{a}$ & $942.66 \mathrm{~b}$ & $31.83 \mathrm{a}$ & $11.44 \mathrm{a}$ & $1074.4 \mathrm{a}$ \\
\hline F- test & $\star \star$ & * & $\star \star$ & $\star \star$ & $\star \star$ & $\star \star$ \\
\hline \multicolumn{7}{|l|}{ K levels: } \\
\hline 24 & $27.11 \mathrm{c}$ & $10.43 \mathrm{c}$ & $826.83 \mathrm{c}$ & $27.01 \mathrm{c}$ & $10.26 \mathrm{c}$ & $874.9 \mathrm{c}$ \\
\hline 36 & $30.09 \mathrm{~b}$ & $11.44 \mathrm{~b}$ & $968.98 \mathrm{~b}$ & $30.31 \mathrm{~b}$ & $11.36 \mathrm{~b}$ & $1028.0 \mathrm{~b}$ \\
\hline 48 & $31.56 \mathrm{a}$ & $13.08 \mathrm{a}$ & $1046.58 \mathrm{a}$ & $33.31 \mathrm{a}$ & $12.04 \mathrm{a}$ & $1144.50 \mathrm{a}$ \\
\hline F-test & $\star \star$ & * & ** & $\star \star$ & $\star \star$ & $\star \star$ \\
\hline F- test interaction & ** & Ns & $\star *$ & $\star *$ & ** & ** \\
\hline
\end{tabular}

RL= Root length (cm), RD = Root diameter (cm), RFW = Root fresh weight (g/plant), *, ** and Ns indicate $p<0.05,<0.01$ and not significant, respectively. Means of each treatment followed by the same letter are not significantly different at $5 \%$ level, according to Duncan's multiple range tests.

Potassium fertilization at rate of $24 \mathrm{~kg} \mathrm{~K} \mathrm{~K}_{2} \mathrm{O} / \mathrm{fed}$ gave the lowest mean values for $\alpha-\mathrm{N}, \mathrm{Na}, \mathrm{K} \%$ and sucrose $\%$ in the two seasons as compared with other levels of potassium. This was compensated by a sufficient increase in root fresh weight/plant, sucrose\% as well as root and sugar yield. Such effect may be due to that potassium fertilizer enhanced the uptake of other minerals which finally reflected in better growth of root and quality, also, due to the especial role of high potassium level that stimulate vegetative growth and hence more essential elements absorbed which increased its level in beet roots at harvest (Moustafa, Shafika et al., 2005). These results are in agreement with those obtained by Alaa et al. (2009) and Awad et al. (2013 b).

Table3: Effect of foliar spraying of mixture of microelements rates and potassium levels on yield of sugar and roots yields and sucrose $\%$ during 2012/2013 and 2013/2014 seasons.

\begin{tabular}{|c|c|c|c|c|c|c|}
\hline \multirow{2}{*}{\begin{tabular}{|c|} 
Traits \\
$\begin{array}{c}\text { Micoelements } \\
\text { rates }\end{array}$ \\
\end{tabular}} & \multicolumn{3}{|c|}{ 2012/2013 season } & \multicolumn{3}{|c|}{ 2013/2014 } \\
\hline & \multicolumn{2}{|c|}{ Yields (ton/fed.) } & \multirow{2}{*}{ Sucrose $\%$} & \multicolumn{2}{|c|}{ Yields (ton/fed.) } & \multirow{2}{*}{ Sucrose\% } \\
\hline (I/fed.) & $\begin{array}{c}\text { Root } \\
\text { yields }\end{array}$ & $\begin{array}{l}\text { Sugar } \\
\text { yields }\end{array}$ & & Root yields & $\begin{array}{l}\text { Sugar } \\
\text { yields }\end{array}$ & \\
\hline 1.0 & $25.73 \mathrm{c}$ & $4.31 \mathrm{c}$ & $16.60 \mathrm{c}$ & $25.96 \mathrm{c}$ & $4.43 \mathrm{c}$ & $16.89 \mathrm{~b}$ \\
\hline 1.5 & $27.74 \mathrm{a}$ & $4.75 \mathrm{a}$ & $16.99 a$ & $28.66 \mathrm{a}$ & $4.98 \mathrm{a}$ & $17.30 \mathrm{a}$ \\
\hline 2.0 & $26.02 b$ & $4.40 \mathrm{~b}$ & $16.73 \mathrm{~b}$ & $26.49 \mathrm{~b}$ & $4.52 \mathrm{~b}$ & $16.86 \mathrm{~b}$ \\
\hline F- test & ** & $\star *$ & ** & ** & $\star *$ & $* *$ \\
\hline \multicolumn{7}{|l|}{ K levels: } \\
\hline 24 & $24.07 \mathrm{c}$ & $3.79 \mathrm{c}$ & $15.69 \mathrm{c}$ & $24.35 c$ & $3.85 \mathrm{c}$ & $15.88 \mathrm{c}$ \\
\hline 36 & $26.69 \mathrm{~b}$ & $4.53 \mathrm{~b}$ & $16.9 \mathrm{~b}$ & $27.20 \mathrm{~b}$ & $4.74 \mathrm{~b}$ & $17.23 \mathrm{~b}$ \\
\hline 48 & $28.74 \mathrm{a}$ & $5.13 \mathrm{a}$ & $17.73 \mathrm{a}$ & $29.56 \mathrm{a}$ & $5.34 \mathrm{a}$ & $17.94 \mathrm{a}$ \\
\hline F- test & ** & $\star \star$ & ** & $\star *$ & ** & ** \\
\hline $\begin{array}{l}\text { F- test } \\
\text { interaction }\end{array}$ & ** & * & ** & ** & * & ** \\
\hline
\end{tabular}

${ }^{*}$, ** and Ns indicate $\mathrm{p}<0.05,<0.01$ and not significant, respectively. Means of each treatment followed by the same letter are not significantly different at $5 \%$ level, according to Duncan's multiple range tests. 
Table 4: Effect of foliar spraying of mixture of microelements rates and potassium levels on Root impurities \% during 2012/2013 and 2013/2014 seasons.

\begin{tabular}{|c|c|c|c|c|c|c|}
\hline \multirow{2}{*}{\begin{tabular}{|c|} 
Traits \\
Microelements rates \\
\end{tabular}} & \multirow{2}{*}{\multicolumn{3}{|c|}{$\begin{array}{l}\text { 2012/2013 season } \\
\text { Root impurities \% }\end{array}$}} & \multicolumn{3}{|c|}{$2013 / 2014$} \\
\hline & & & & & t impur & \\
\hline$(\mathrm{l} /$ fed. $)$ & $\alpha-N$ & $\mathrm{Na}$ & $\mathrm{K}$ & $\alpha-N$ & $\mathrm{Na}$ & $\mathrm{K}$ \\
\hline 1.0 & $1.43 \mathrm{~b}$ & $1.62 \mathrm{~b}$ & $3.21 \mathrm{~b}$ & $1.31 \mathrm{~b}$ & $1.71 \mathrm{~b}$ & $3.07 \mathrm{~b}$ \\
\hline 1.5 & $1.32 \mathrm{c}$ & $1.57 \mathrm{~b}$ & $3.06 \mathrm{c}$ & $1.25 \mathrm{c}$ & $1.49 \mathrm{c}$ & $2.95 \mathrm{C}$ \\
\hline 2.0 & $1.57 \mathrm{a}$ & 2.06 & $3.43 \mathrm{a}$ & $1.44 \mathrm{a}$ & $2.05 \mathrm{a}$ & $3.22 \mathrm{a}$ \\
\hline F- test & ** & * & ** & $* *$ & ** & ** \\
\hline Potassium levels: & & & & & & \\
\hline 24 & $1.14 \mathrm{c}$ & $1.63 \mathrm{c}$ & $2.82 \mathrm{c}$ & $1.12 \mathrm{c}$ & $1.64 \mathrm{c}$ & $2.71 \mathrm{c}$ \\
\hline 36 & $1.48 \mathrm{~b}$ & $1.76 \mathrm{~b}$ & $3.36 \mathrm{~b}$ & $1.34 \mathrm{~b}$ & $1.75 \mathrm{~b}$ & $3.18 \mathrm{~b}$ \\
\hline 48 & $1.70 \mathrm{a}$ & $1.86 \mathrm{a}$ & $3.51 \mathrm{a}$ & $1.53 \mathrm{a}$ & $1.88 \mathrm{a}$ & $3.34 \mathrm{a}$ \\
\hline F- test & ** & * & ** & $\star \star *$ & ** & $\star \star$ \\
\hline F- test interaction & ** & Ns & ** & $\star \star$ & $\star \star *$ & $\star \star$ \\
\hline
\end{tabular}

Root impurities \% (g/100 g DW), i.e. ( $\alpha-\mathrm{N}=\alpha$-amino nitrogen, $\mathrm{Na}=$ sodium, $\mathrm{K}=$ potassium). *, $\star \star$ and Ns indicate $p<0.05,<0.01$ and not significant, respectively. Means of each treatment followed by the same letter are not significantly different at $5 \%$ level, according to Duncan's multiple range tests.

\section{Effect of interactions:}

Results in Tables 5 mentioned that the interaction between foliar spraying of $\mathrm{B}, \mathrm{Fe}, \mathrm{Zn}$ and $\mathrm{Mn}$ at different concentrations and potassium fertilizer levels affected significantly root and sugar yields/fed and sugar\%, the high mean values of these characters were obtained when fertilized at rate of $48 \mathrm{~kg} \mathrm{~K}_{2} \mathrm{O} / \mathrm{fed}$ and foliar spraying of $\mathrm{B}, \mathrm{Fe}, \mathrm{Zn}$ and $\mathrm{Mn}$ at rate of 1.5 $\mathrm{l} / \mathrm{fed}$ in both seasons. On the other hand foliar spraying of $\mathrm{B}, \mathrm{Fe}, \mathrm{Zn}$ and $\mathrm{Mn}$ at rate of $1.0 \mathrm{l} / \mathrm{fed}$ and $24 \mathrm{~kg} \mathrm{~K} \mathrm{~K}_{2} \mathrm{O} / \mathrm{fed}$ gave the lowest root and sugar yields/fed and sugar\% in both seasons. The beneficial effects of the studied micronutrients and potassium are more related to their active role for building new meristemic cells, enhanced cell elongation and increased the ability rate of leaves for photosynthetic process. The beneficial effect of the interaction between these micronutrients may be attributed to each one by increasing plant growth or maintaining favorable balance between them. The positive effect of micronutrients as individually or mixture on sugar beet plants was also reported by Soudi and El-Guibali (2008), Alaa et al. (2009), Manal, Hussein (2011) and Awad et al. (2013 a).

Table 5: Effect of the interaction between foliar spraying of mixture of microelements rates and potassium levels on roots \& sugar yield and Sugar\% during 2012/2013 and 2013/2014 seasons.

\begin{tabular}{|c|c|c|c|c|c|c|c|}
\hline \multicolumn{4}{|c|}{ Interaction } & \multicolumn{9}{|c|}{ Seasons } \\
\cline { 2 - 8 } & \multicolumn{2}{|c|}{$\mathbf{2 0 1 2 / 2 0 1 3}$} & \multicolumn{3}{c|}{$\mathbf{2 0 1 3 / 2 0 1 4}$} \\
\hline $\begin{array}{c}\text { Microelements } \\
\text { rates (I/fed.) }\end{array}$ & $\begin{array}{c}\text { Potassium } \\
\text { levels }\end{array}$ & $\begin{array}{c}\text { Roots } \\
\text { yield }\end{array}$ & $\begin{array}{c}\text { Sugar } \\
\text { yield }\end{array}$ & Sugar \% & Roots yield & $\begin{array}{c}\text { Sugar } \\
\text { yield }\end{array}$ & Sugar \% \\
\hline \multirow{3}{*}{1.0} & 24 & $23.17 \mathrm{f}$ & $3.66 \mathrm{f}$ & $15.52 \mathrm{~h}$ & $23.60 \mathrm{~h}$ & $3.77 \mathrm{~h}$ & $15.79 \mathrm{~g}$ \\
\cline { 2 - 8 } & 36 & $23.02 \mathrm{c}$ & $4.33 \mathrm{~d}$ & $16.67 \mathrm{e}$ & $26.13 \mathrm{e}$ & $4.48 \mathrm{f}$ & $17.01 \mathrm{~d}$ \\
\cline { 2 - 8 } & 48 & $27.99 \mathrm{~b}$ & $4.92 \mathrm{c}$ & $17.61 \mathrm{~b}$ & $28.14 \mathrm{c}$ & $5.05 \mathrm{~d}$ & $17.88 \mathrm{~b}$ \\
\hline \multirow{3}{*}{1.5} & 24 & $25.23 \mathrm{~d}$ & $3.97 \mathrm{e}$ & $15.87 \mathrm{f}$ & $25.47 \mathrm{f}$ & $4.07 \mathrm{~g}$ & $25.47 \mathrm{f}$ \\
\cline { 2 - 8 } & 36 & $27.95 \mathrm{~b}$ & $4.86 \mathrm{c}$ & $17.24 \mathrm{c}$ & $28.76 \mathrm{~b}$ & $5.14 \mathrm{c}$ & $17.78 \mathrm{c}$ \\
\hline \multirow{3}{*}{2} & 48 & $30.07 \mathrm{a}$ & $5.41 \mathrm{a}$ & $17.87 \mathrm{a}$ & $31.75 \mathrm{a}$ & $5.73 \mathrm{a}$ & $18.05 \mathrm{a}$ \\
\hline & 24 & $23.8 \mathrm{e}$ & $3.75 \mathrm{f}$ & $15.86 \mathrm{~g}$ & $23.98 \mathrm{~g}$ & $3.73 \mathrm{~h}$ & $15.79 \mathrm{~g}$ \\
\cline { 2 - 8 } & 36 & $26.1 \mathrm{c}$ & $4.4 \mathrm{~d}$ & $16.79 \mathrm{~d}$ & $26.71 \mathrm{~d}$ & $4.59 \mathrm{e}$ & $16.88 \mathrm{e}$ \\
\cline { 2 - 8 } & 48 & $28.16 \mathrm{~b}$ & $5.05 \mathrm{~b}$ & $17.7 \mathrm{~b}$ & $28.79 \mathrm{~b}$ & $5.23 \mathrm{~b}$ & $17.9 \mathrm{~b}$ \\
\hline
\end{tabular}




\section{CONCLUSION}

It is concluded that foliar application of $\mathrm{B}, \mathrm{Fe}, \mathrm{Zn}$ and $\mathrm{Mn}$ at rate of $1.5 \mathrm{l} / \mathrm{fed}$ and fertilized with potassium at rate of $48 \mathrm{~kg} \mathrm{~K} \mathrm{~K}_{2} \mathrm{O} / \mathrm{fed}$ produced highest sugar beet yield and yield component.

\section{REFERENCES}

Abd El-Gawad, A.M.; S.A.H. Allam; Laila, M.A.Saif and A.M.H. Osman (2004). Effect of some micronutrients on yield and quality of sugar beet, juice quality and chemical compositions. Egypt. J. Agric. Res., 82 (4): 1681-1701.

Abdel-motagally, M.F. Fathy and K. Attia (2009) Response of sugar beet plants to nitrogen and potassium fertilization in sandy calcareous soil. J Agric \& Bio., 11: 695-700.

Alaa I.B., N.M.M.Awad and Sahar M.Ibrahim (2009). Productivity and quality of sugar beet as affected by rates of potassium and some micronutrients under two locations. Minufiya J.Agric.Res.34(6):21312144.

A.O.A.C. (2005). Official Methods of Analysis. Published by the A.O.A.C., Box 540, Washington, D.C.

Awad, N. M.M.; Sahar,F.Tawfik and Sahr,M.I.Moustafa (2013 a).Influence of foliar spray of some micronutrients and nitrogen fertilizer on productivity of sugar beet under newly reclaimed soils. J. Agric. Res. Kafr El-Sheikh Univ. 39(2):181-194.

Awad, N. M.M.; H.S.Gharib and Sahr, M.I.Moustafa (2013 b). Response of sugar beet (Beta vulgaris L.) to potassium and sulphur supply in clayed soil at North Delta, Egypt. Egypt. Agron. 35(1):77-99.

Bichsel, S. E. (1987). An overview of the U.S. sugar beet industry. Proceedings of the Symposium on the chemistry and processing of sugar beet. Denver, Colorado. $108 \mathrm{pp}$.

CCSC (2010). Central Council for Sugar Crops. Ann. Report, Ministry of Agric., Egypt. (In Arabic).

Devlin, R.M. and F.H. Witham (1983). Plant Physiology. $4^{\text {th }}$ Ed. Wadads worth publishing Company. A Division of Wadsworth, Inc. Belmont, California.

Duncan, B.D. (1955). Multiple ranges and multiple F-Test Biometrics, 11:142.

El-Geddawy, I.H.; K.A. Kheiralla; Y.Y.I. Darweish and E.A.M. Sharaf (2008). Agricultural practices in relation to quality of sugar beet yield and yield components. Sugar Tech, Springer India, 10 (3): 227-233.

El-Geddawy, I.H.; M.S. Osman; M.G.A. Taha and S.A.A.M. Enan (2007). Transplanting using paper pots technique and micronutrition with relation to yield and it is attributes of sugar beet at different planting dates. Egypt. J. Agric. Res., 85 (1): 191-209. 
El-Harriri, D.M. and M. E. Gobarh. (2001). Response of growth, yield and quality of sugar beet to nitrogen and potassium fertilizers under newly reclaimed sandy soil. J. Agric. Sci. Mansoura Unvi., 26 (10): 5895 5907.

El-Maghraby, S. S.; M. M. Shehata and Y. H. Tawfik. (1998). Effect of soil and foliar application of nitrogen and potassium on sugar beet. Egypt. J. Agric. Res., 76 (2): 665-678.

EL-Shafai, A.M.A. (2000). Effect of nitrogen and potassium fertilization on yield and quality of sugar beet in Sohag. Egypt, J.Agric.Res., 78 (2);759-767.

Gezgin, S.; B. Sade; M.Hamurcu; N. Dursun; M. Ouder and M. Baduaglu (2000). Effect of various B, Zn and NPK levels on the yield and sugar content of sugar beet. Proceeding of the International Work Shop Boron, 2001. Univ.; Bonn, Bonn, Germany, 23-28 June, 2001.

Gomez, K.A. and A.A. Gomez (1984). Statistical procedures for Agricultural Research. John Wiley and Sons, Inc., New York.

Hellal, F.A.; A.S. Taalab and A.M. Safaa (2009). Influence of nitrogen and boron nutrition on nutrient balance and sugar beet yield grown in calcareous soil. Ozen. J. Appl. Sci., 2 (1): 1943-2429.

Ismail,A.M.A., kh.A.Aboushady and S.M..Allam(2002) Response of some sugar beet varieties to methods of potassium application. Egypt, Appl. Sci., 17(2):86-101.

Karam, F.; Y. Rouphael; R. Lahoud; J. Breidi and G. Colla (2009). Influence of genotypes and potassium applicationrates on yield and potassium use efficiency of potato. J. Agron, 8(1): 27-32.

Khalil, S. M.; S. N. Mostafa and Z. R. Mostafa (2001). Influence of potassium fertilizer and soil salinity on chemical composition of sugar beet root. Minufiya J. Agric. Res., 26(3): 583 - 594.

Le Docte, A. (1927). Commercial determination of sugar beet root using the Sacks Le-Docte Process. Int. Sugar J., 29: 488-492.

Mahdi Mehrandis; M. J. Moeini and M. Armin (2012). Sugar beet (Beta vulgaris L.) response to potassium application under full and deficit irrigation. European Journal of Experimental Biology, 2(6):2113-2119.

Manal, Hussein, Y. (2011). Using some microelements and fungicide in controlling root rot disease of sugar beet. Egypt. J. Appl. Sci., 26 (2): 20-28.

Marschner, H. (1986). Mineral nutrition of higher plants. Acad. Press. Pp 186.

Moustafa, Shafika, N.; Safaa, S.M. El-Sayed; A.M.E. Gomma and Zeinab R. Moustafa (2005). Response of sugar beet varieties to $\mathrm{N}$ and Sulphur as foliar application. Egypt. J. Appl. Sci., 20 (9): 45-58.

Nabila, M. Zaki; M.S. Hassanein; Amal, G. Ahmed; Ebtsam, A. El-Housini and M.M. Tawfik (2014). Foliar application of potassium to mitigate the adverse impact of salinity on some sugar beet varieties. 2: Effect on yield and quality, Middle East Journal of Agriculture Research, 3(3): 448-460. 
Nafei ,A.I.; A.M.H.Osman and Maha,M. EL-zeny (2010). Effect of plant densities and $\mathrm{K}$-fertilization rates on yield and quality of sugar beet crop in sandy reclaimed soils. J.Plant Prod.,Mansoura Univ., 1(2): 229-237.

Ohki, K. (1978). Zn concentration in soybean as related to early growth photosynthesis and carbon anhydrase activity. Crop Sci., 18: 79-82.

Osman, A.M.H. (1997). Effect of some micronutrients on yield and quality of sugar beet, juice quality and chemical compositions. M.Sc. Thesis Fac. Agric. Moshtohor Zagazig Univ. Banha Branch., Egypt.

Osman, A.M.H. (2005). Influence of $\mathrm{N}$ and $\mathrm{K}$ fertilization on yield and quality of two sugar beet varieties. Egypt. J. Agric. Res., 83 (3): 1237-1254.

Osman, A.M.H.; G.S. El Sayed and A.I. Nafei (2004). Effect of foliar application date of $\mathrm{B}$ and bioconstituents (Yeast Extraction) on yield and quality of sugar beet. Egypt. J. Appl. Sci., 19 (2): 76-98.

Rengel, $Z$ and P. Damon (2008). Crops and genotypes differ in efficiency of potassium uptake and use. Physiol. Plant., 133(4):624-636.

Salami, M. and S. Saadat (2013). Study of potassium and nitrogen fertilizer levels on the yield of sugar beet in jolge cultivar. J Nov. Appl Sci., 2(4): 94-100.

Sandman, G. and P. Bogger (1983). The enzymological function of heavy metals and their role in electron transfer processes of plant. In: Inorganic nutrition. Encycl. Plant Physiol., New Series, 15 B, Springer Verlag Berlin. Hiedelberg, New York, Tokyo. pp 563-596.

Shafika, N.M. and A.A. El-Masry (2006). Effect of nitrogen and potassium fertilization with or without spraying by Fe combined with $\mathrm{Mn}$ on some physic and chemical properties, productivity and quality of sugar beet crop. Ann. Agric. Sci. Moshtohor, 44 (4): 1431-1446.

Soudi, Amal, K.M. and Amal H. El-Guibali (2008). Effect of foliar application with some micronutrients on yield and quality of sugar beet. Egypt. J. Appl. Sci., 23 (3): 41-51.

Taiz, L and E. Zeiger (2006). Plant Physiology (4th Ed.).

Ulgen, A.; A. U. Gokmen; S. H. Herdem and H. Cengiz (2009). Development of a $635 \mathrm{~nm}$-Laser Diode Spectrometer for Continuous Monitoring of Amino Nitrogen in the Beet Sugar Industry. Instrumentation Science \& Technology, 37(2): 218-229.

Vendergeten, I. and M. Venstaleen (1991). Wirkung einer reihenweisen Plazierung von optimalen nitrogen Mengen auf Ertrag und auf industrielle Qualitat der Zuckerrube. $54^{\text {th }}$ Winter Cong. of the Inter. Inst. Sugar Beet Res., 297-319

Watson, L. and M. J. Dallwitz (1992). "The Families of Flowering Plants: Descriptions, Illustrations, Identification, and Information Retrieval."Version $: 15^{\text {th }} \quad$ October 1998. Http://biodiversity.uno.edu/delta/.

Zengin, M.; G. Fatma; M.Y. Atilla and S. Gez Gin (2009). Effect of potassium, magnesium and sulphur containing fertilizers on yield and quality of sugar beets (Beta vulgaris L.). Turk J. Agric., 33: 495-502. 
تأثير الرش بتركيزات العناصر الصغرى والتسميد البوتاسى على النمو والصفات

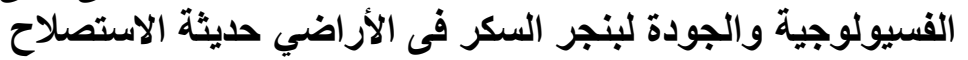

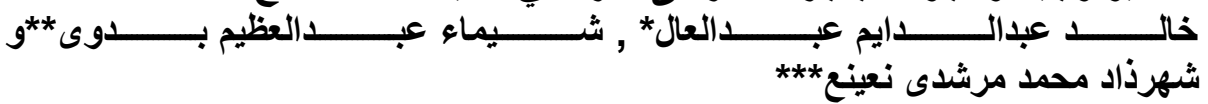

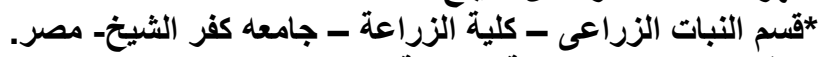

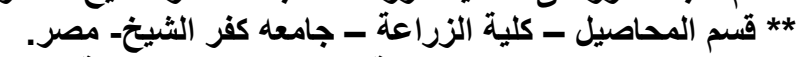

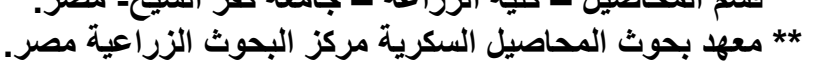

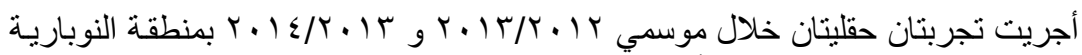

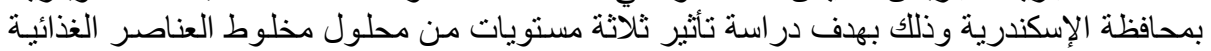

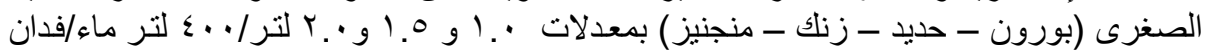

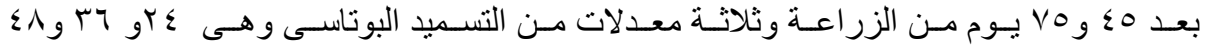

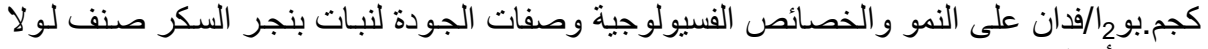

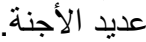

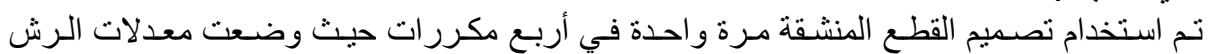
بالعناصر الغذائية الصغرى في القطع الرئيسية ووضئعت معدلات التهرئ التسميد البوتاسى في القطع الثقية

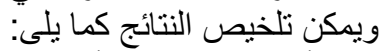

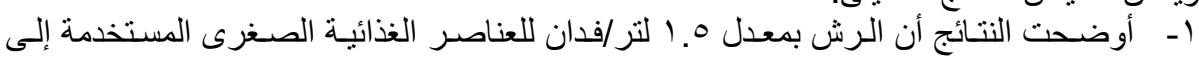

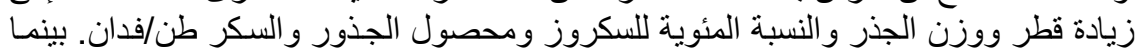

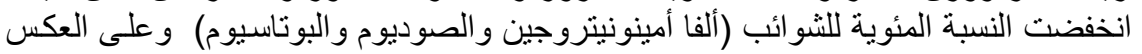

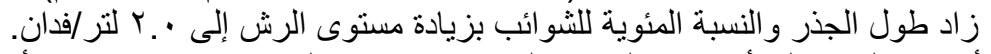

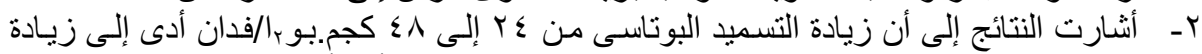

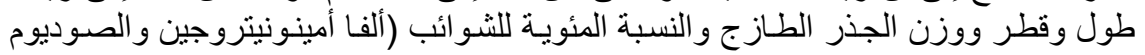

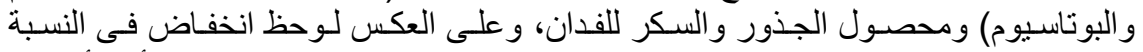

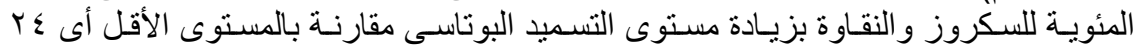

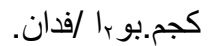

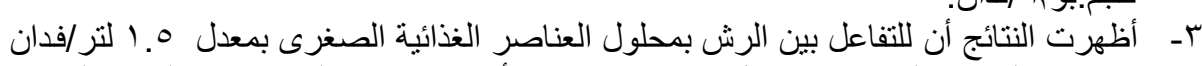

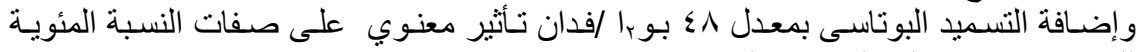

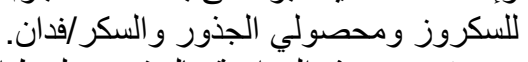

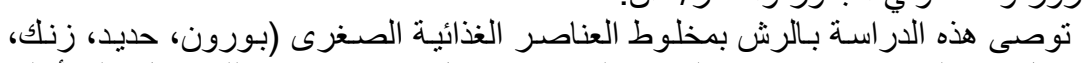

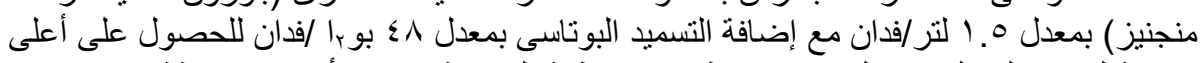

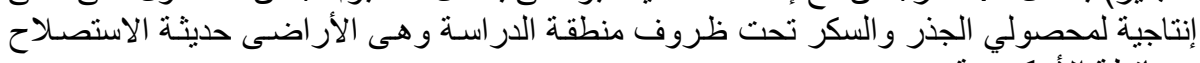

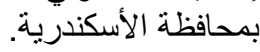

